\title{
MAGIC- is it for real?
}

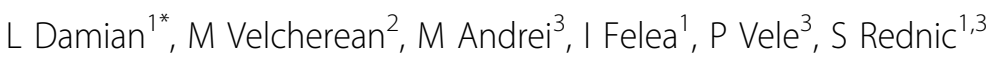 \\ From 8th International Congress of Familial Mediterranean Fever and Systemic Autoinflammatory Diseases \\ Dresden, Germany. 30 September - 3 October 2015
}

\section{Question}

MAGIC syndrome, an acronym for mouth and genital ulcers with inflammed cartilage, is a rare condition described in 1985 [1]. About 20 cases have been reported [2], and its existence is challenged, as it could be just a mere association of Bechet's disease (BD) with relapsing polychondritis (RP) [3]. Other authors, however, consider it a distinct entity with higher risk of aortic aneurysms [4]. We tried to find out whether this syndrome is a true nosologic entity.

\section{Methods}

We retrospectively reviewed our tertiary referral centre's database from 2000 to 2015 in order to identify the cases of RP and BD. All patients fulfilled the International Criteria for BD [5] and the Damiani-Levine criteria for RP [6].

\section{Results}

Three cases have been identified, all diagnosed with MAGIC's syndrome since the first presentation. No other case evolved into MAGIC after an initial diagnosis of RP or BD. Hematological screening was negative in all patients; one had gastrointestinal vasculitis and another one panniculitis. No one in our series had eye or CNS involvement. Aortic aneurysms were absent (as yet) in the 2 patients searched for. Azathioprine, colchicine and corticotherapy were employed effectively in all patients.

\section{Conclusion}

$\mathrm{RP}$ and BD have overlapping features and may share pathogenetic mechanisms. The same time of onset of the main MAGIC clinical features could favour the classification of the disease as distinct from RP and BD alone. However, in our small and incompletely followed-up series aortic aneurysms were not seen, like in other MAGIC cases reported. An aortic follow-up is nevertheless advisable, as in any RP.

\section{Authors' details \\ ${ }^{1}$ Emergency Clinical County Hospital Cluj, Rheumatology, Cluj-Napoca, Romania. ${ }^{2}$ Emergency County Hospital Deva, Rheumatology, Deva, Romania. 3"Iuliu Hatieganu" University of Medicne and Pharmacy Cluj, Rheumatology, Cluj-Napoca, Romania.}

Published: 28 September 2015

\section{References}

1. Firestein GS, Gruber E, Weisman MH, Zvaifler NJ, Barber J, O'Duffy JD: Mouth and genital ulcers with inflamed cartilage: MAGIC syndrome. Am J Med 1985, 79(1):65-72.

Table 1 Clinical features of MAGIC patients in our series

\begin{tabular}{|c|c|c|c|c|c|}
\hline Case & $\begin{array}{l}\text { Sex } \\
\text { age }\end{array}$ & Clinical features & Therapy & $\begin{array}{l}\text { Aortic } \\
\text { involvement }\end{array}$ & Outcome \\
\hline$\overline{1}$ & $F, 63$ & $\begin{array}{l}\text { oral aphtae since youth; genital aphtae, deep vein thrombosis, migratory seronegative } \\
\text { polyarthritis, reccurent bilateral auricular chondritis, wheesing }\end{array}$ & $\begin{array}{l}\text { CS, } \\
\text { AZA,Col }\end{array}$ & NK & $\begin{array}{l}\text { Lost to follow-up } \\
\text { (after } 2 \text { years) }\end{array}$ \\
\hline 2 & $F, 35$ & $\begin{array}{l}\text { bipolar aphtae, asymmetric sacroiliitis, acneiform rash, intermittent seronegative } \\
\text { polyarthritis, gastrointestinal involvement, bilateral auricular and nasal chondritisANA } \\
\text { positive, dsDNA negative }\end{array}$ & $\begin{array}{l}\text { CS, } \\
\text { AZA, Col }\end{array}$ & $\mathrm{No} / \mathrm{NK}$ & $\begin{array}{l}\text { Lost to follow-up } \\
\text { (after } 3 \text { years- } \\
\text { emigrated) }\end{array}$ \\
\hline 3 & $M, 2$ & $\begin{array}{l}\text { bipolar aphtae, pseudofolliculitis, erythema nodosum, arthritis, panniculitis, recurrent } \\
\text { auricular chondritis, nasal chondritis, positive cartilage biopsy }\end{array}$ & $\begin{array}{l}\text { CS, } \\
\text { AZA,Col }\end{array}$ & No & Rare chondritis flares \\
\hline
\end{tabular}

$\mathrm{CS}=$ corticosteroids, Col=colchicine, $\mathrm{AZA}=$ azathioprine

\footnotetext{
'Emergency Clinical County Hospital Cluj, Rheumatology, Cluj-Napoca,

Romania

Full list of author information is available at the end of the article
}

(c) 2015 Damian et al. This is an Open Access article distributed under the terms of the Creative Commons Attribution License (http:// creativecommons.org/licenses/by/4.0), which permits unrestricted use, distribution, and reproduction in any medium, provided the original work is properly cited. The Creative Commons Public Domain Dedication waiver (http://creativecommons.org/publicdomain/ zero/1.0/) applies to the data made available in this article, unless otherwise stated. 
2. Wajed J, Kiely P: 19. Could it be Magic? Rheumatology 2011, 50(Suppl 3): iii43-iii50.

3. Kotter J, Deuter C, Gunaydin I, Zierhut M: MAGIC or not MAGIC (mouth and genital ulcers with inflamed cartilage) syndrome really exists? A case report and review of the literature. Clin Exp Rheumatol 2006, 24(5 Suppl 42):S108-S112.

4. Hidalgo-Tenorio C, Sabio-Sanchez JM, Linares PJ, Salmeron LM, Ros-die E, Jimenez-Alonso J: Magic syndrome and true aortic aneurysm. Clin Rheumatol 2008, 27(1):115-117.

5. Kronborg C, Mahar PD, Kelly R: Should we keep changing the diagnostic criteria for Behcet's disease? Dermatology 2014, 228(1):1-4

6. Damiani JM, Levine HL: Relapsing polychondritis- report of ten cases. Laryngoscope 1979, 89(6 Pt 1):929-946.

doi:10.1186/1546-0096-13-S1-P156

Cite this article as: Damian et al:: MAGIC- is it for real? Pediatric

Rheumatology 2015 13(Suppl 1):P156.

Submit your next manuscript to BioMed Central and take full advantage of:

- Convenient online submission

- Thorough peer review

- No space constraints or color figure charges

- Immediate publication on acceptance

- Inclusion in PubMed, CAS, Scopus and Google Scholar

- Research which is freely available for redistribution

Submit your manuscript at www.biomedcentral.com/submit 